\title{
A new species of Lemmermanniella (Cyanobacteria) from the Atlantic Rainforest, Brazil ${ }^{1}$
}

\author{
WATSON ARANTES GAMA JUNIOR ${ }^{2,5}$, MARIA TERESA DE PAIVAAZEVEDO ${ }^{2}$, \\ JAROSLAVA KOMÁRKOVÁ-LEGNEROVÁ ${ }^{3,4}$ and CÉLIA LEITE SANT’ANNA²
}

(received: March 29, 2012; accepted: September 06, 2012)

\begin{abstract}
A new species of Lemmermanniella (Cyanobacteria) from the Atlantic Rainforest, Brazil). The Brazilian Atlantic Rainforest is a highly heterogeneous ecosystem comprising large numbers of tropical and subtropical habitats favorable to the development of cyanobacteria. Studies on cyanobacteria in this ecosystem are still rare, however, especially those involving unicellular and colonial types. The high biodiversity and endemism of this biome has been extremely impacted and fragmented, and less than $10 \%$ of its original vegetation cover remains today. We describe here a new species of a colonial cyanobacteria, Lemmermanniella terrestris, found on dry soils in a subtropical region of the Atlantic Rainforest in the municipality of Cananéia in southern São Paulo State, Brazil. This new taxon demonstrated all of the diacritical features of the genus Lemmermanniella but, unlike the other species of the genus, it was growing on the soil surface and not in an aquatic environment. A set of morphological features, including colonies composed of subcolonies, and cell dimensions, shapes and contents distinguish it from other species of the genus. Considering that species of Lemmermanniella are found in very distinct habitats (such as thermal and brackish waters) and that they maintain the same life cycle described for the genus in all of those environments, the morphological structures of the colonies can be used as reliable markers for identifying the genus, and its species differ primarily in relation to the habitats they occupy.
\end{abstract}

Key words - Chroococcales, Lemmermanniella terrestris, terrestrial habitat

\section{INTRODUCTION}

The Atlantic Rainforest originally covered most of the tropical and subtropical Brazilian coast, but is now restricted to a matrix of fragments, mainly in southern and southeastern Brazil (Rizzini 1997). This biome comprises many habitat types, each with its own distinct microclimate (Mittermeier et al. 1999). The Atlantic Rain Forest is considered as one of the five most important global hotspots for conservation due to its huge biodiversity, elevated endemism, and high degree of fragmentation (Myers et al. 2000). The Atlantic Rainforest originally covered $68 \%$ of São Paulo State, but is currently restricted to only $10.7 \%$ of its original area (SOS Mata Atlântica \& Inpe 2011).

Many investigators have examined Cyanobacteria diversity in the Atlantic Rainforest, mostly in terrestrial habitats. Three new genera (Fiore et al. 2007, Sant'Anna

1. Part of the master's dissertation of first author, Programa de PósGraduação em Biodiversidade Vegetal e Meio Ambiente, Instituto de Botânica, SP, Brazil.

2. Instituto de Botânica, Núcleo de Pesquisa em Ficologia, Caixa Postal 3005, 01031-970 São Paulo, SP, Brazil.

3. University of South Bohemia, Faculty of Biology, Branišovska 31, CZ-370 05 Česke Budějovice, Czech Republic.

4. Czech Academy of Sciences, Institute of Hydrobiology, Na sadkach 7, CZ-370 05 Česke Budějovice, Czech Republic.

5. Corresponding author: watsonarantes@gmail.com et al. 2010) and 27 new species (Sant'Anna et al. 1991a,b, 2007, 2010, 2011a,b, Azevedo \& Sant'Anna 1994a,b, Branco et al. 1994, 2006, Azevedo \& Kováčik 1996, Komárek 2003, Fiore et al. 2007, Lemes-da-Silva et al. 2010) have recently been described in different terrestrial habitats of the Atlantic Rainforest, with all three new genera and $55 \%$ of the new species belonging to Nostocales. These studies are not yet sufficient, however, to determine the full extent of cyanobacteria diversity in this biome, and there are still environments and groups that have not yet been intensively investigated.

One of the least studied groups of Cyanobacteria is composed of unicellular and colonial organisms traditionally treated as coccoid morphotypes. Their simple cell shapes make their morphological differentiation and specific determinations very difficult and little is known about these organisms in terms of their diversity and distribution, making it impossible to construct their biogeographical profiles (Hoffmann 1996), lending importance to studies of coccoid Cyanobacteria, especially those inhabiting terrestrial environments.

The coccoid Cyanobacteria genus Lemmermanniella was first proposed by Geitler (1942). After its original description, however, additional representatives of Lemmermanniella were rarely found, and the few published records were restricted to temperate zones; populations from tropical (Azevedo et al. 1999, Komárek 
\& Komárková-Legnerová 2007) and subtropical (Juárez \& Wenzel 2003) sites have only recently been reported. Two species were originally described from tropical areas: L. obesa M.T.P.Azevedo et al., from a Brazilian brackish lagoon, and L. uliginosa Komárek \& Komárková-Legnerová, from marshes in Belize.

In the present study a new species of Lemmermanniella is described found growing on soils in a subtropical area of the Atlantic Rainforest.

\section{MATERIAL AND METHODS}

The material examined was encountered on dry soil crusts (mixed with gravel) exposed to full sunlight (figure 1) in the municipality of Cananéia, São Paulo State,

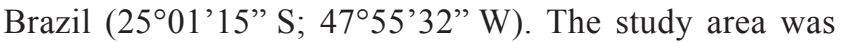
located at sea level and was surrounded by a preserved fragment of Atlantic Rainforest. The regional climate is characterized by high temperature and humidity levels, with rainy summers but no well-defined dry season (Funari et al. 1987).

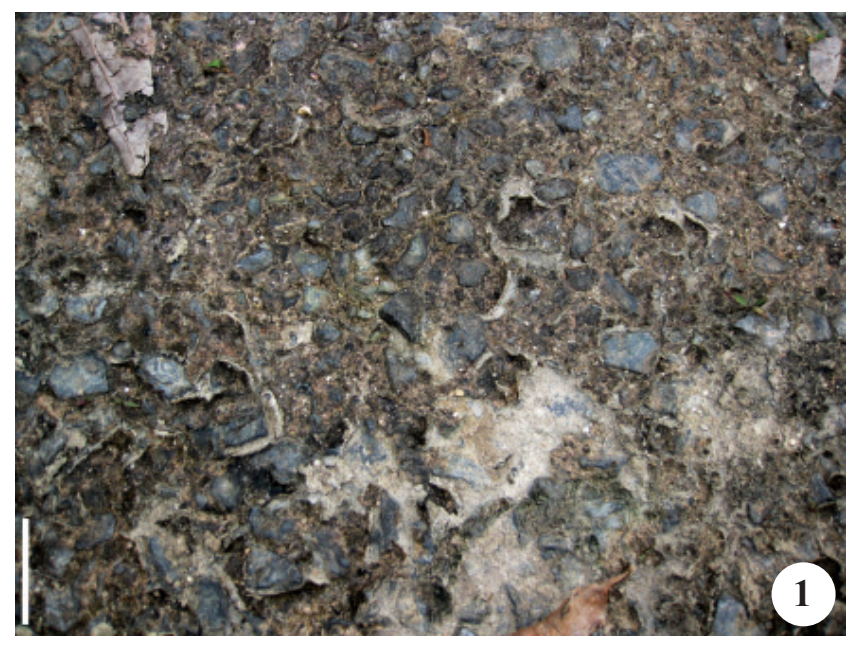

Figure 1. General aspect of the soil crusts where Lemmermanniella terrestris sp. nov. was found. Bar $=10 \mathrm{~cm}$.

The samples were gathered with a spatula, with one portion being kept dry while another was fixed in $4 \%$ formaldehyde. The dry material was rehydrated in the laboratory with distillated water (in Petri dishes) for 24 hours before being examined under a light microscope. We analyzed 20 distinct colonies and measured 10 cells from each to describe the morphological and metric features of the population. Epifluorescence microscopy was used to test for the presence of phycocyanin and chlorophyll, pigments not found in other groups of bacteria. A $1 \%$ methylene blue solution was used to stain the mucilage envelope.

\section{RESULTS}

Lemmermanniella terrestris W.A. Gama-Jr., sp. nov. Figures 2-8

Colonies spherical to elongated, 43.7-243.7 $\mu \mathrm{m}$ in diameter, subcolonies frequently present, 10.2-16.9 $\mu \mathrm{m}$ in diameter. Mucilage inconspicuous, hyaline. Cells ellipsoidal, with pointed to rounded (rarely) apices, 2.57.1(8.8) $\mu \mathrm{m}$ in diameter $\times 1.4-2.5 \mu \mathrm{m}$ long, $1.7-2.8$ times longer than wide, loosely arranged under the mucilage surface, rarely forming dense groups. Pseudofilaments rare, 3-5 cells long. Cell contents granulated, pale blue-green to grey. Reproduction by disintegration of the colonies or by separation of small clusters of cells from the mother colony.

Habitat: found together with other cyanobacteria (Nostoc-dominant, Scytonema, Chroococcus) on dry soil crusts mixed with gravel and exposed to direct sunlight.

Type locality: Brazil, municipality of Cananéia, São Paulo State $\left(25^{\circ} 01^{\prime} 15^{\prime \prime} \mathrm{S} ; 47^{\circ} 55^{\prime} 32^{\prime \prime} \mathrm{W}\right)$.

Diagnosis: Coloniae sphaericae ad elongatas, 43.7-243.7 $\mu \mathrm{m}$ in diam., sub-coloniae frequenter presentes, 10.2-16.9 um diam. Mucusinconspicuus, hyalinus. Cellulae ellipsoideae, apicibus punctiformibus rare rotundatis, 2.5-7.1(8.8) × 1.4-2.5 um, 1.7-2.8-plo longiores quam latiores, laxe dispersae in involucro mucoso, rare densas catervas formantes. Pseudofilamenta rara, 3-5 cellulis praedita. Contentumcellularegranulare, pallideglaucumad cinereum. Multiplication a coloniis rupentibus vel a parvis fasciculis mucosis cellularibus ex colonia matrice.

Typus (Holotypus): Exsiccatum SP 401446; dep. in herbarium (SP) Instituti Botanicae, SP, Brazil; icona typica figurae nostrae 2-3.

Habitatio: crustae soli secci glarea mixtae directe sub luce solari expositae.

Locus classicus: Brasilia, provincia São Paulo, in

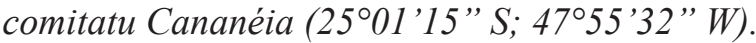

\section{DISCUSSION}

The genus Lemmermanniella has been problematic ever since first being proposed by Geitler (1942). Due to the lack of precision in the descriptions of the type species and nomenclatural conflicts, Hindák (1985) undertook a revision of this genus and reestablished its diacritical morphological features: 1) hollow colonies, and 2) cells with their long axes parallel to the colony surface. These characteristics make this genus distinct from Aphanothece, and Epigloeosphaera, respectively, and match those found in the population studied here. 

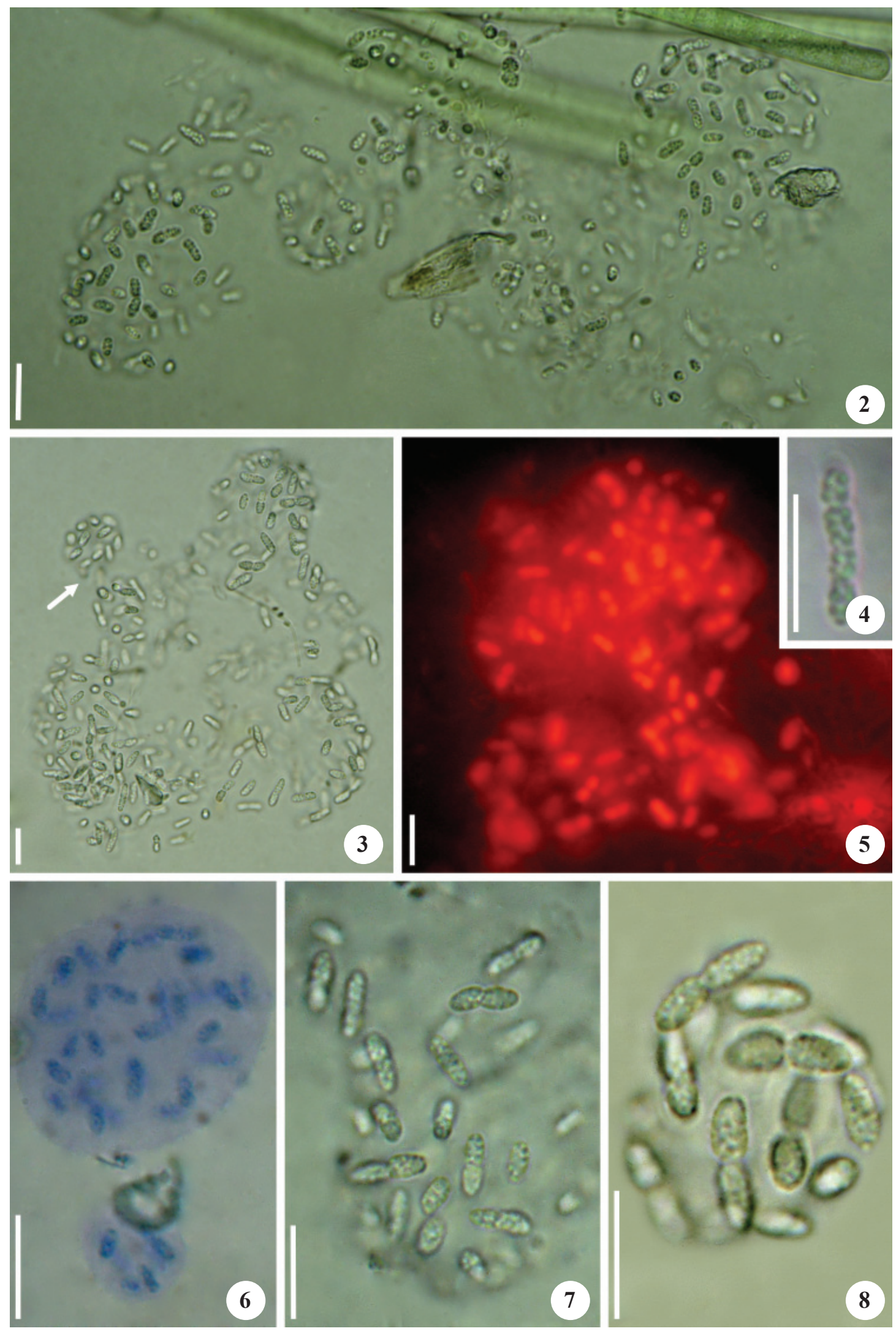

Figures 2-8. Lemmermanniella terrestris sp. nov. 2. General aspect of a colony, showing subcolonies. 3. Mature colony liberating a young colony (arrow). 4. Detail of a pseudofilament. 5. Colony aspect under epifluorescence microscopy. 6. Colony stained by methylene blue. 7 . Detail of disintegrating colony. 8. Young colony. Bar $=10 \mu \mathrm{m}$. 
Lemmermanniella is also similar to the genus Rhabdogloea in terms of cell shape, cell division in one plane, and the presence of pseudofilaments. However, the arrangements of their cells in the mucilage matrices are completely different (Komárek \& Anagnostidis 1998), as thecells of Rhabdogloea species are distributed throughout the mucilaginous colony while Lemmermanniella species always have their cells arranged in a single layer beneath the mucilage surface. Hindák (1985) also highlighted the fact that Lemmermanniella species always show cells in a single layer at the periphery of the colonial mucilage, with pseudofilaments rarely been observed characteristics that correspond perfectly to the material gathered in the Atlantic Rainforest.

The newly described morphotype from the Atlantic Rainforest is distinguishable from other closely related species (table 1) mainly by the following features: 1) occurrence in a very specific habitat (soil) distinct from the aquatic habitats of all of the other species; 2) new colonies constantly being formed from subcolonies, which is only observed in the other species when they are reproducing; 3) presence of pseudofilaments; and 4) their cell shapes, dimensions and contents.

Difficulties encountered in obtaining successful cultures of many cyanobacteria have made molecular studies of this group to be very difficult. Johansen \& Casamatta (2005) suggested that new taxa could be described based solely on their morphological features if the new morphotypes were distinguishable from existing species in terms of specific ecological and morphological characteristics. The validity of these criteria was supported by a number of recent works using molecular techniques that showed clear differentiations of ecologically distinct cyanobacterial species (Flechtner et al. 2002, Casamatta et al. 2006, Řeháková et al. 2007, Taton et al. 2010). Likewise Gaylarde et al. (2005) demonstrated that species from aerial habitats are genetically distinct from aquatic species of the same genus. Based on these examples, we can conclude that the features presented by Lemmermanniella terrestris sp. nov. are sufficient to distinguish it from other Lemmermanniella species.

All species of Lemmermanniella share the distinct morphology described for the type species, in spite of their occurrence in very different habitats such as marshes (L. uliginosa), brackish waters (L. obesa), pools with thermal water inflows (L. flexa Hindák), and terrestrial sites in the Atlantic Rainforest (L. terrestris). These results show that colony structure is an important diacritical feature at the generic level, and that species differ mainly in relation to their habitats.

Table 1. Comparison of Lemmermanniella terrestris sp. nov. with its most closely related species.

\begin{tabular}{|c|c|c|c|c|}
\hline & $\begin{array}{l}\text { L. pallida Lemmermann } \\
\text { Geitler (Komárek \& } \\
\text { Anagnostidis 1998) }\end{array}$ & $\begin{array}{l}\text { L. uliginosa Komárek \& } \\
\text { Komárková-Legnerová } \\
\text { (Komárek \& Komárková- } \\
\text { Legnerová 2007) }\end{array}$ & $\begin{array}{l}\text { L. obesa Azevedo et al. } \\
\text { (Azevedo et al. 1999) }\end{array}$ & L. terrestris sp. nov. \\
\hline Cell arrangements & $\begin{array}{l}\text { irregular, more or less } \\
\text { densely distributed in } \\
\text { the surface layer }\end{array}$ & $\begin{array}{l}\text { irregular in one } \\
\text { subsurface layer }\end{array}$ & $\begin{array}{l}\text { irregular in one layer } \\
\text { (sometimes two layers) }\end{array}$ & $\begin{array}{l}\text { irregular, loosely } \\
\text { dispersed under the } \\
\text { mucilage envelope }\end{array}$ \\
\hline Sub-colonies & $\begin{array}{l}\text { present during } \\
\text { reproduction }\end{array}$ & Present during reproduction & $\begin{array}{l}\text { present during } \\
\text { reproduction }\end{array}$ & constantly present \\
\hline Pseudofilaments & absent & absent & absent & present \\
\hline Cell diameter $(\mu \mathrm{m})$ & $0.5-1.6$ & $(2.5) 3.0-3.4$ & $2.6-3.9$ & $1.4-2.5$ \\
\hline Cell length $(\mu \mathrm{m})$ & $(0.7) 1-3.7(4.7)$ & $(4.6) 6.2-10.0(12.4)$ & $5-6.8$ & $2.5-7.1(8.8)$ \\
\hline Length/Diameter & - & - & 1.7 & 2.4-3.1 \\
\hline Cell contents & $\begin{array}{l}\text { homogeneous, pale blue- } \\
\text { green }\end{array}$ & $\begin{array}{l}\text { finely granular, pale blue- } \\
\text { green }\end{array}$ & $\begin{array}{l}\text { homogeneous, dark } \\
\text { blue-green }\end{array}$ & $\begin{array}{l}\text { granular, pale } \\
\text { blue-green to grey }\end{array}$ \\
\hline Habitat & plankton in lakes & benthic in alkaline marshes & $\begin{array}{l}\text { plankton in brackish } \\
\text { waters }\end{array}$ & $\begin{array}{l}\text { terrestrial on dry } \\
\text { soil crusts }\end{array}$ \\
\hline Occurrence & Baltic area & Belize & Brazil & Brazil \\
\hline Cell forms & & & & \\
\hline
\end{tabular}


Acknowledgements - We thank CNPq (Process number 562213/2010-4) for financial support, Capes for the fellowship awarded to the first author, and the Pos-graduate Program of Instituto de Botânica for financial support. We are also grateful to Dr. Tarciso Filgueiras for the Latin diagnosis.

\section{REFERENCES}

Azevedo MTP, Kováčik L. 1996. Rhabdogloea brasilica sp. nov. (Chroococcales, Synechococcaceae): morphological and morphometric variability under cross-gradient cultures. Algological Studies 83:83-92.

Azevedo MTP, Sant'AnnaCL.1994a. Cyanostylongelatinosus, a new species (Chroococcales, Cyanophyceae) from São Paulo State, Brazil. Algological Studies 75:75-78.

Azevedo MTP, Sant'Anna CL. 1994b. Hormothece geitleriana: a new edaphic chroococcal Cyanophyceae from São Paulo State, Brazil. Algological Studies 75: 79-83.

Azevedo MTP, Souza CA, Menezes M. 1999. Synechococcaceae (Cyanophyceae/Cyanobacteria) from a tropical brackish water lagoon, Brazil. Algological Studies 94:45-61.

Branco LHZ, Azevedo MTP, Sant'Anna CL, Komárek J. 2006. New morphospecies of Symplocastrum (Phormidiaceae, Oscillatoriales) from aerophytic habitats in Brazil. Algological Studies 121:23-33.

Branco LHZ, Silva SM, Sant'Anna CL. 1994. Stichosiphon mangle sp. nova, a new cyanophyte from mangrove environments. Algological Studies 72:1-7.

Casamatta DA, Gomez SR, Johansen JR. 2006. Rexia erecta gen. et sp. nov. and Capsosira lowei sp. nov., two newly described cyanobacterial taxa from the Great Smoky Mountains National Park (USA). In Advances in algal biology: a commemoration of the work of Rex Lowe (RJ Stevenson, Y Pan, JP Kociolek, JE Kingston, eds.). Developments in Hydrobiology 185: 13-26.

Fiore MF, Sant'Anna CL, Azevedo MTP, Komárek J, Kaštovský J, Sulek J,Lorenzi,A. 2007. The cyanobacterial genus Brasilonema - molecular and phenotype evaluation. Journal of Phycology 43:789-798.

Flechtner VR, Boyer SL, Johansen JR, DeNoble ML. 2002. Spirirestis rafaelensis gen. et sp. nov. (Cyanophyceae), a new cyanobacterial genus from arid soils. Nova Hedwigia 74:1-24.

Funari FL, De Vuono YS, Salum ST. 1987. Balanço hídrico de duas áreas de Mata Atlântica: Reserva Biológica de Paranapiacaba e Parque Estadual da Ilha do Cardoso (São Paulo). In Anais do IV Congresso da Sociedade Botânica de São Paulo, Sociedade Botânica de São Paulo, São Paulo, p.95-101.

Gaylarde PM, Crispim CA, Neilan BA, Gaylarde CC. 2005. Cyanobacteria from Brazilian building walls are distant relatives of aquatic genera. Omics 9:30-42.
Geitler L. 1942. Schizophyta: Klasse Schizophyceae. In Die natürlichen Pflanzenfamilien, Zweite Auflage, vol.1b (A Engler, K Prantl, eds.). Wilhelm Engelmann, Leipzig.

Hindák F. 1985. The Cyanophycean genus Lemmermanniella Geitler 1942. Algological Studies 40:393-401.

Hoffmann L. 1996. Geographic distribution of freshwater blue-green algae. Hydrobiologia 336:33-40.

Johansen JR, Casamatta DA. 2005. Recognizing cyanobacterial diversity through adoption of a new species paradigm. Algological Studies 117:71-93.

Juárez AB, Wenzel MT. 2003. Lemmermanniella flexa Hindák (Cyanoprokaryota, Chroococcales) in South America. Algological Studies 108:1-6.

Komárek J, Anagnostidis K. 1998. Cyanoprokaryota, 1: Chroococcales. In Süsswasserflora von Mitteleuropa (H Ettl, G Gärtner, H Heynig, D Möllenhauer, eds.). Gustav Fischer, Stuttgart, v.19, p.1-548.

Komárek J, Komárková-Legnerová J. 2007. Taxonomic evaluation of the cyanobacterial microflora from alkaline marshes of northern Belize. 1. Phenotypic diversity of coccoid morphotypes. Nova Hedwigia 84:65-111.

Komárek J. 2003. Two Camptylonemopsis species (cyanoprokaryotes) from "Mata Atlântica" in coastal Brazil. Preslia 75:223-232.

Lemes-da-Silva NM, Branco LHZ, Necchi Junior O. 2010. New aerophytic morphospecies of Cyanobacteria from tropical forest fragments in northwestern São Paulo state, Brazil. Acta Botanica Brasilica 24:916-923.

Mittermeier RA, Myers N, Robles-Gil P, Mittermeier CG. 1999. Hotspots. Earth's biologically richest and most endangered terrestrial ecoregions. Cemex/Agrupación Sierra Madre, Ciudad de México.

Myers N, Mittermier RA, Mittermier CG, Fonseca GAB, Kent J. 2000. Biodiversity hotspot for conservation priorities. Nature 403:845-853.

Řeháková K, Johansen JR, Casamatta DA, Xuesong L, Vincent J. 2007. Morphological and molecular characterization of selected desert soil cyanobacteria: three species new to science including Mojavia pulchra gen. et sp. nov. Phycologia 46:481-502.

Rizzini CT. 1997. Tratado de fitogeografia do Brasil. 2nd ed., Âmbito Cultural Edições Ltda, Rio de Janeiro.

Sant'Anna CL, Azevedo MTP, Branco LHZ, Komárek J. 2007. New aerophytic morphospecies of Nostoc (Cyanobacteria) from São Paulo State, Brazil. Hoehnea 34:95-101.

Sant'Anna CL, Azevedo MTP, Fiore MF, Lorenzi AS, Kaštovský J, Komárek J. 2011a. Subgeneric diversity of Brasilonema (Cyanobacteria, Scytonemataceae). Revista Brasileira de Botânica 34:51-62.

Sant'Anna CL, Azevedo MTP, Kaštovsky J, Komárek J. 2010. Two form-genera of aerophytic heterocytous cyanobacteria from Brazilian rainy forest "Mata Atlântica". Fottea 10:217-228. 
Sant'Anna CL, Gama Junior WA, Azevedo MTP, Komárek J. 2011b. New morphospecies of Chamaesiphon (Cyanobacteria) from the Atlantic Rainforest, Brazil. Fottea 11:25-30.

Sant'Anna CL, Silva SMF, Branco LHZ. 1991a. Cyanophyceae da Gruta-que-chora, município de Ubatuba, Estado de São Paulo, Brasil. Hoehnea 18:75-97.

Sant'Anna CL, Branco LHZ, Silva SMF. 1991b. Anew species of Gloeothece (Cyanophyceae, Microcystaceae) from São Paulo State, Brazil. Algological Studies 62:1-5.
SOS Mata Atlântica, Inpe - Fundação SOS Mata Atlântica, Instituto Nacional de Pesquisas Espaciais. 2011. Atlas dos Remanescentes Florestais da Mata Atlântica Período 2008-2010. Fundação SOS Mata Atlântica, Instituto Nacional de Pesquisas Espaciais, São Paulo.

Taton A, Wilmotte A, Šmarda J, Elster J, Komárek J. 2010. Plectolyngbya hodgsonii: a novel filamentous cyanobacterium from Antarctic lakes. Polar Biology 34:181-191. 